\title{
Differences in size and growth rates of male and female migrating Japanese eels in Pearl River, China
}

\author{
W. N. TzenG*‡, H. R. Lin†, C. H. WANG* AND S. N. XU* \\ *Department of Zoology, College of Science, National Taiwan University, No. 1, Sec. 4, \\ Roosevelt Rd., Taipei, Taiwan 106, ROC and $\dagger$ School of Life Science, Zhongshan \\ (Sun Yet-Sen) University, Guangzhou 510275, PROC
}

(Received 13 January 2000, Accepted 21 June 2000)

\begin{abstract}
The Sr/Ca ratios in otoliths of silver Japanese eels Anguilla japonica in Pearl River, China, indicated that both sexes did not stay in brackish water and grew in fresh water from the glass eel stage until spawning migration. This did not support the hypothesis that females tended to distribute upstream and males might be restricted to estuaries. The back-calculated total length of males at glass eel stage was not significantly different from that of females, indicating that the hypothesis that small glass eels became males and larger ones became females may not be true. The mean ( \pm S.D.) age and total length of males at migration were $6.4 \pm 1.6$ years and $48.3 \pm 4.5 \mathrm{~cm}$, which were significantly smaller than for females, $8.3 \pm 1.6$ years and $61 \cdot 4 \pm 4 \cdot 1 \mathrm{~cm}$. The age of migration was related inversely to growth rate for both sexes. Growth parameters of the von Bertalanffy growth equation were $K=0.21 \mathrm{~cm}$ year ${ }^{-1}$,

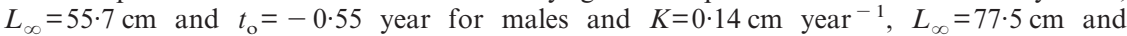
$t_{\mathrm{o}}=-0.60$ year for females. The difference in asymptotic length $\left(L_{\infty}\right)$ between males and females may be because females postpone migration to achieve larger size for maximizing reproductive success.

(C) 2000 The Fisheries Society of the British Isles
\end{abstract}

Key words: eel; age; growth; otolith; microchemistry; migration.

\section{INTRODUCTION}

The Japanese eel Anguilla japonica Temminck and Schlegel is distributed from the Philippines in the south, through Taiwan, mainland China and Korea to Japan in the north (Tesch, 1977). The eel is a commercially important cultured species in these Asian countries (Tzeng, 1985). It spawns in the Pacific Ocean west of Mariana Islands $\left(14-16^{\circ} \mathrm{N} ; 134-143^{\circ} \mathrm{E}\right)$ (Tsukamoto, 1992) in June and July (Tzeng, 1990). The eel larvae (leptocephali) migrate on the North Equatorial and the Kuroshio Currents to the coast, metamorphose to glass eels on the continental shelf, and then migrate to estuaries. As they move upriver, they become pigmented and are called elvers. For culture, glass eels are harvested in estuaries during their upstream migration in winter (Tzeng, 1985). The time for eel larvae to migrate from the oceanic spawning ground to the estuaries is c. 5-6 months (Tzeng, 1990; Tzeng \& Tsai, 1992, 1994; Cheng \& Tzeng, 1996). Most glass eels migrate upstream and grow in fresh water until maturation, but some of them may stay in brackish water until maturation (Tsukamoto et al., 1998; Tzeng et al., 2000). In late autumn when the eels

†Author to whom correspondence should be addressed. Fax: 8862 23639570; email: wnt@ ccms.ntu.edu.tw 
become mature, they metamorphose from yellow eels to silver eels and migrate downstream to the ocean for spawning (Tesch, 1977).

Otoliths of silver eels provide a complete history of the growth of individual eels, so that variation in growth may be observed between the sexes and within each of the sexes at all stages of their life history (Poole \& Reynolds, 1996). Meanwhile the strontium ( $\mathrm{Sr}$ ) : calcium (Ca) ratio in otoliths is correlated positively with the ambient salinity in which fish growth, and it is feasible to track ontogenetic shifts in habitat use, especially by anadromous and catadromous fishes (Kalish, 1990; Tzeng, 1995, 1996; Tzeng et al., 1997, 1999, 2000).

In comparison with the American eel $A$. rostrata (Le Sueur) and the European eel $A$. anguilla (L.), the growth history of the Japanese eel has not been well studied. The age and growth of Japanese eel have been studied recently for the yellow eel stage, but without discriminating sexes (Guan et al., 1994). Female eels grow faster than males in European eel (Rossi \& Colombo, 1976; Vøllestad \& Jonsson, 1986; Poole \& Reynolds, 1996) and in the American eel (Helfman et al., 1987). However, Holmgren \& Mosegaard (1996) indicated that males grew faster than females at sizes where the gonads were not completely differentiated. It is not known if the sexes of the Japanese eel grow at different rates. Vladykov (1966) proposed that small glass eels of American eels became males, whereas larger glass eels became females. Helfman et al. (1987) noted that females tended to distribute upstream, while males might be restricted to estuaries. To test these hypotheses, the age and growth of Japanese eels collected during their downstream spawning migration were studied by sex. The migratory environmental history of each sex was determined by the $\mathrm{Sr}: \mathrm{Ca}$ ratios in otoliths.

\section{MATERIALS AND METHODS}

Silver Japanese eels were collected during their downstream spawning migration in a bag net along the riverbank at Fan-Yu in the lower Pearl River, c. 200-250 km from the South China Sea, in October and November 1996. The mean water temperature at the study site was $29^{\circ} \mathrm{C}$ in the summer and $15.4^{\circ} \mathrm{C}$ in the winter.

For each eel collected, total length was measured to the nearest $0.5 \mathrm{~cm}$. Then the eels were dissected and sexes were determined from the histology of the gonad. The largest pair of otoliths (sagitta) were extracted, dried at $60^{\circ} \mathrm{C}$ for $10 \mathrm{~min}$, embedded in a silicon rubber mould with petropoxy 154 (Palouse Petro Procuts, U.S.A.). Each otolith was ground and polished from the proximal side with sandpaper until the primordium was revealed, and then coated with carbon. Strontium $(\mathrm{Sr})$ and calcium $(\mathrm{Ca})$ concentrations were measured with a wavelength-dispersive X-ray spectrometer (Shimadzu-ARL-EMXSM7). In the analyses of $\mathrm{Sr}$ and $\mathrm{Ca}, \mathrm{SrTiO}_{3}$ and $\mathrm{CaSO}_{4}$ were used as standards. The acceleration voltage of electrons was $15 \mathrm{kV}$ and specimen current $0.01 \mu \mathrm{A}$. The electron beam was focused on an area $c .5 \mu \mathrm{m}$ in diameter at intervals of 20 and $50 \mu \mathrm{m}$, respectively, along the anterior-posterior axis of the otoliths (Tzeng \& Tsai, 1994). The temporal changes in $\mathrm{Sr}: \mathrm{Ca}$ ratios of eight randomly selected otoliths were used to reconstruct the previous migratory environmental history of each sex of the eels (Tzeng et al., 1997).

After electron microprobe analysis, the otoliths were repolished and etched with $5 \%$ EDTA (ethylene diamine tetra-acetate, $\mathrm{pH}$ adjusted with $\mathrm{NaOH}$ to $7 \cdot 4$ ) for 3 min to enhance the annuli (Tzeng et al., 1994). The annuli were discriminated using a transmitted light microscope. Age was determined by counting annuli in the otolith. A total of 74 eels was examined for age determination. 
The radii from primordium to glass eel mark $\left(r_{\mathrm{o}}\right)$, annuli $\left(r_{\mathrm{n}}\right)$ and the edge of otolith $(R)$ were measured. Then total lengths at glass eel stage $\left(l_{\mathrm{o}}\right)$ and at annulus formation period $\left(l_{\mathrm{n}}\right)$ were estimated respectively by the Dahl-Lea formula (Francis, 1990):

$$
l_{\mathrm{n}}=r_{\mathrm{n}} L R^{-1}
$$

where, $L$ is total length of the silver eel at capture. Mean $l_{\mathrm{n}}$ was used to estimate the growth parameters of the von Bertalanffy growth equation by Ford-Walford plot (Ricker, 1958).

The significance of difference in mean values $l_{\mathrm{o}}$ and $l_{\mathrm{n}}$ between the sexes was examined by the $t$-test. Mean absolute growth rate $(G)$ of the silver eels was calculated according to the formula:

$$
G=\left(L-l_{\mathrm{o}}\right) t^{-1}
$$

where, $l_{\mathrm{o}}$ is total length at glass eel stage as estimated from $r_{\mathrm{o}}, t$ is the age of silver eels estimated from the counts of annuli in the otolith. Then the age of silver eels at downstream spawning migration in relation to their growth rate $(G)$ was calculated by sex.

\section{RESULTS}

\section{AGE AND GROWTH}

Figure 1 shows the glass eel mark located $c .145 \mu \mathrm{m}$ from the primordium, and the subsequent five annuli on the sagittal plane of a $65-\mathrm{cm}$ female silver eel otolith. The mark was formed as the glass eel arrived at the estuary. Beyond the mark, there are five fast growth opaque zones and five slow growth translucent zones (annuli). The annuli were dark under the transmitted light microscope.

The ages of silver females at downstream spawning migration (5-10 years, mean $8 \cdot 3 \pm 1 \cdot 6)$ were significantly higher than those of males (4-10 years, mean $6.4 \pm 1.6)(P<0.001)$. Similarly, total lengths of females $(50.5-70.5 \mathrm{~cm}$, mean $61.44 \pm 4.05)$ were significantly greater than lengths of males $(42.0$ $59.0 \mathrm{~cm}$, mean $48.32 \pm 4.48)(P<0.001)$. Weights of females $(160-490 \mathrm{~g}$, mean $384 \cdot 14 \pm 70 \cdot 91)$ were also significantly greater than those of males $(95-250 \mathrm{~g}$, mean $145 \cdot 61 \pm 38 \cdot 86)(P<0 \cdot 001)$ (Table I). These indicate that the male and female eels develop and mature according to different life history strategies, males using a time-minimizing strategy and maturing at a smaller size while females using a size-maximizing strategy by postponing the age at migration.

Ages of the eels at downstream spawning migration were correlated negatively with the mean growth rates for both sexes, indicating that faster-growing eels became silver before slower-growing ones (Fig. 2).

The back-calculated mean ( \pm S.D.) total length at glass eel stage was not significantly different between males $\left(l_{\mathrm{o}}=5.23 \pm 0.95 \mathrm{~cm}\right)$ and females $(5.62 \pm 0.95 \mathrm{~cm})(P=0 \cdot 107)$. The back-calculated $l_{\mathrm{o}}$ was close to the total length of glass eels during upstream migration in the estuary (Cheng \& Tzeng, 1996). In addition, the mean total lengths for each of the ages up to 5 years old were not significantly different between males and females $(P=0 \cdot 086-0 \cdot 300)$. But beyond 6 years old, the lengths of females were significantly greater than those of males $(P<0 \cdot 001)$ (Fig. 3).

A theoretical growth curve of the eels was fitted by the von Bertalanffy growth equation for both sexes (Fig. 3), and the growth parameters were 


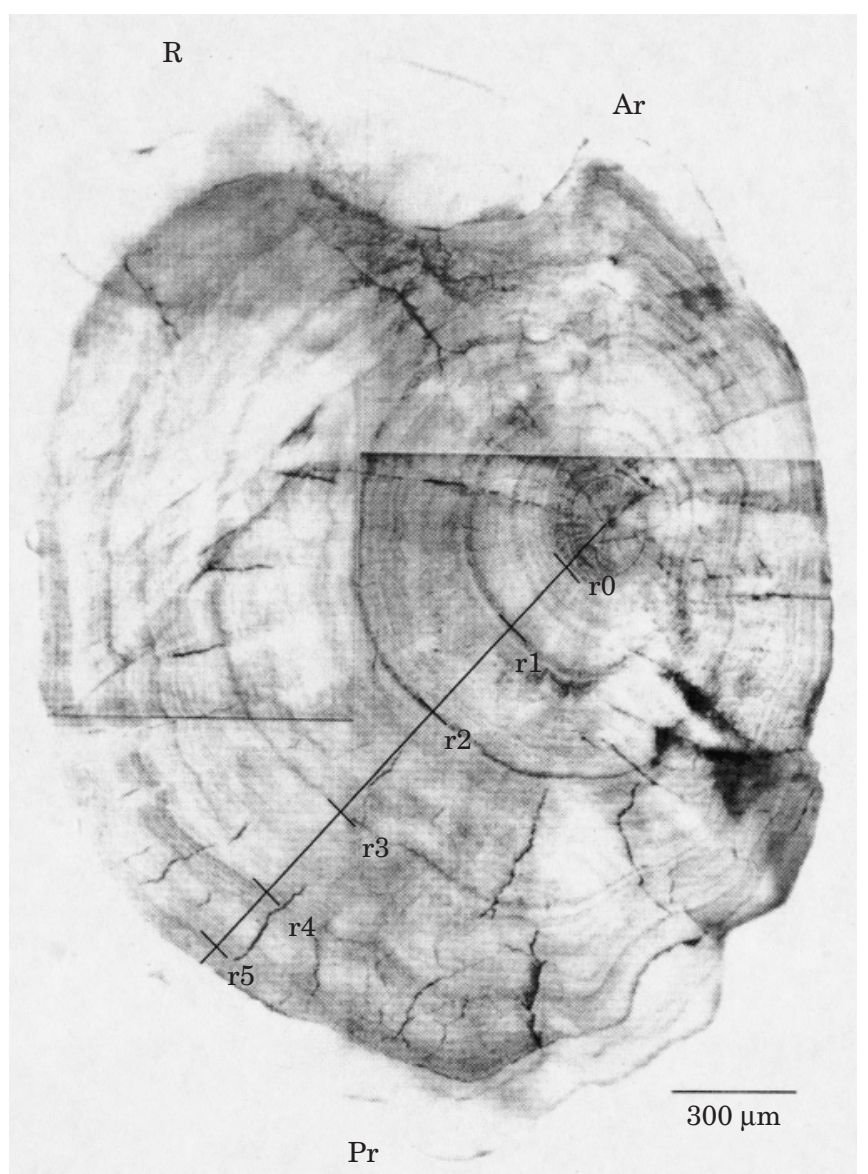

FIG. 1. Photograph showing glass eel mark $\left(\mathrm{r}_{0}\right)$ and annuli $\left(\mathrm{r}_{1-5}\right)$ on the otolith of a $65 \mathrm{~cm}$ female eel, Anguilla japonica (R, rostrum; Ar, antirostrum; Pr, postrostrum).

TABLE I. Differences in age, total length and body weight of the silver Japanese eels at downstream spawning migration between males and females

\begin{tabular}{|c|c|c|c|c|c|c|}
\hline & Sex & $n$ & Range & Mean & S.D. & $P$-value \\
\hline Total length (cm) & $\hat{0}$ & 38 & $42 \cdot 0-59 \cdot 0$ & $48 \cdot 32$ & $\begin{array}{l}4 \cdot 48 \\
4.05\end{array}$ & $<0 \cdot 001$ \\
\hline Body weight (g) & $\begin{array}{l}7 \\
0 \\
0 \\
0\end{array}$ & $\begin{array}{l}36 \\
38 \\
36\end{array}$ & $\begin{array}{c}50 \cdot 3-10 \cdot 5 \\
95 \cdot 0-250 \cdot 0 \\
160 \cdot 0-490 \cdot 0\end{array}$ & $\begin{array}{r}01 \cdot 44 \\
145 \cdot 61 \\
348 \cdot 14\end{array}$ & $\begin{array}{r}4 \cdot 05 \\
38 \cdot 86 \\
70.91\end{array}$ & $<0 \cdot 001$ \\
\hline Age (years) & $\begin{array}{l}+ \\
0 \\
0 \\
0\end{array}$ & 32 & $\begin{array}{c}4-10 \\
5-10\end{array}$ & $\begin{array}{r}340.14 \\
6 \cdot 38 \\
8 \cdot 30\end{array}$ & $\begin{array}{r}1.62 \\
1.62\end{array}$ & $<0 \cdot 001$ \\
\hline
\end{tabular}

$K=0.21 \mathrm{~cm} \mathrm{year}^{-1}$ (male) and $0 \cdot 14 \mathrm{~cm} \mathrm{year}^{-1}$ (female), $L_{\infty}=55 \cdot 7$ and $77 \cdot 5 \mathrm{~cm}$, and $t_{\mathrm{o}}=-0.55$ and -0.60 years. The $K$ was larger and $L_{\infty}$ was smaller in males than females, indicating that males approached the asymptotic length $\left(L_{\infty}\right)$ faster than females. 


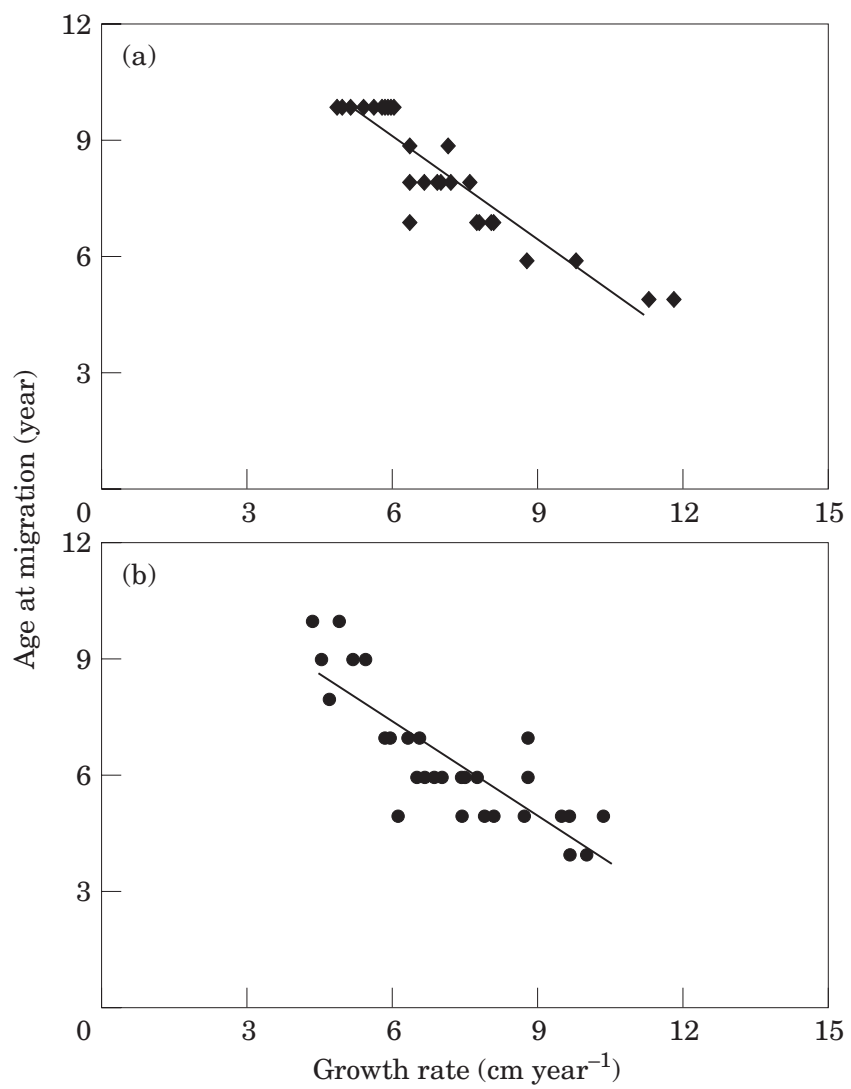

FIG. 2. Correlation between age at downstream spawning migration and growth rate of the silver Japanese eel, A. japonica, (a) female; (b) male. (a) $y=-0 \cdot 87 x+14 \cdot 38 ; r^{2}=0 \cdot 84 ; n=30$. (b) $y=-0 \cdot 81 x+12 \cdot 13 ; r^{2}=0 \cdot 69 ; n=32$.

\section{TEMPORAL CHANGE OF Sr/Ca RATIOS IN OTOLITH}

The time-series change of mean ( \pm S.D.) $\mathrm{Sr}: \mathrm{Ca}$ ratios in the otoliths was similar between males and females (Fig. 4). The ratios were higher in the interval from primordium to $c .100 \mu \mathrm{m}$ from the primordium, and ranged from 8 to $16 \times 10^{-3}$. The otolith for this interval was deposited during the leptocephalus stage of the marine phase. Thereafter, the ratios decreased gradually to a lower level $\left(<1 \cdot 0 \times 10^{-3}\right)$ as the eels migrated into fresh water. The ratios remained c. $4 \cdot 0 \times 10^{-3}$ if the eels had stayed in brackish water (Tzeng et al., 1997). This indicates that both males and females grew in fresh water until the downstream spawning migration.

\section{DISCUSSION}

The growth history of eels is not well understood. It was proposed that females may occur in all appropriate estuarine and fresh waters; while males may be restricted to estuaries (Helfman et al., 1987). If this was true, the $\mathrm{Sr}: \mathrm{Ca}$ ratios in male otoliths should increase after the glass eel stage (Fig. 4). However, 


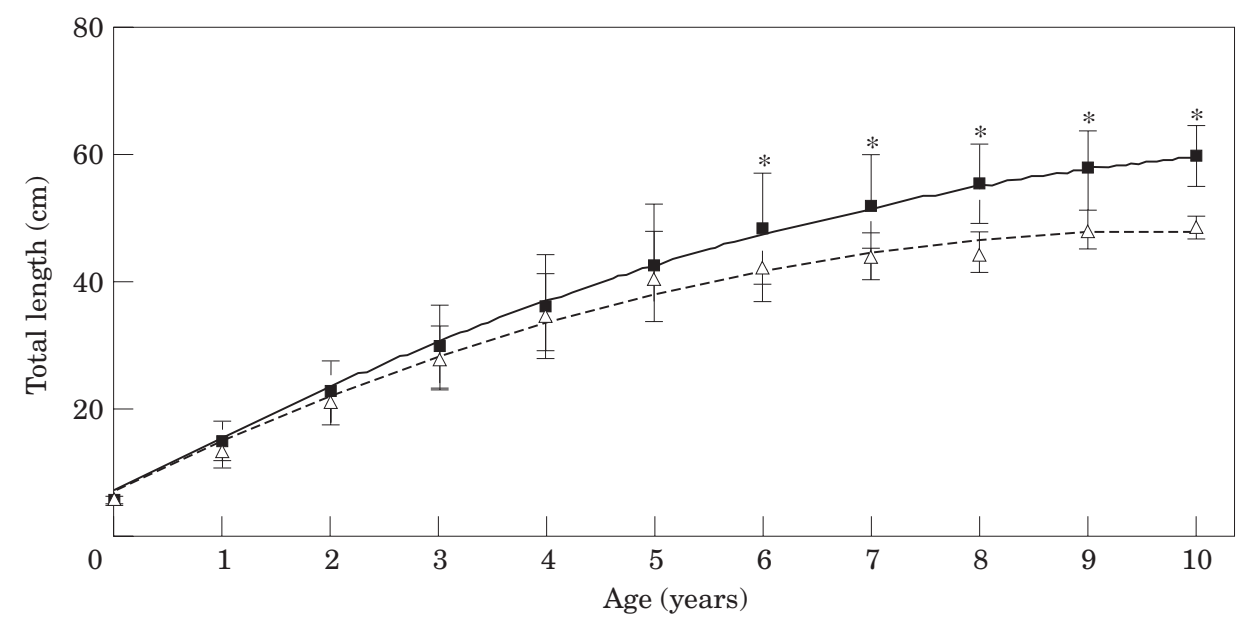

FIG. 3. Growth curves of male $(\triangle)$ and female ( $\boldsymbol{\square})$ Japanese eel $A$. japonica with a comparison of mean total length between the sexes at each age (vertical line, standard deviations): $l_{\mathrm{o}}$ total length at glass eel stage $($ age $=0) ;{ }^{*}$, the mean total length differed between the sexes at $P<0 \cdot 001$.

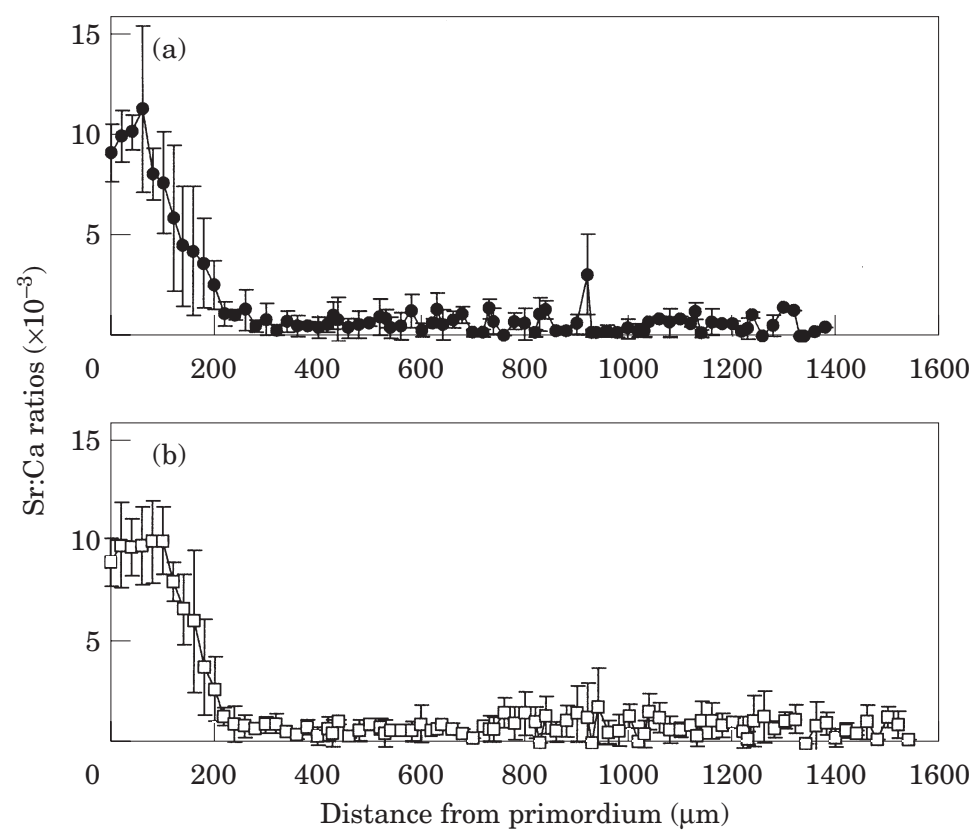

FIG. 4. Time series changes in mean ( \pm S.D.) $\mathrm{Sr}$ : Ca ratios in otoliths of silver eels, $A$. japonica: (a) male, $n=4$; (b) female, $n=4$.

this was not the case. This indicates that males in this study left the estuary after the glass eel stage. However, it is not known if there is a segment of the male population that stayed in the estuary, because fish caught in the estuary were not examined. 
The sex of the eel cannot be determined at the glass eel stage (Rossi \& Colombo, 1976). From a geographic decline in size-sex relationship, Vladykov (1966) proposed that smaller glass eels of American eels became males, whereas larger glass eels became females. A similar mechanism was proposed also for European eels (Bellini, 1970; Kuhlman, 1975). However, the back-calculated total length of the eel at the glass eel stage $\left(l_{\mathrm{o}}\right)$ was not significnatly different between males and females. This indicates that Vladykov's (1966) hypothesis may not be true.

Many studies on the European eel indicated that females grew faster than males (Vøllestad \& Jonsson, 1986; Vøllestad, 1992; Poole \& Reynolds, 1996). On the contrary, Holmgren \& Mosegaard (1996) indicated that there was no consistent difference in absolute length increase between small males and females, but below 40-60 g initial body weights, males displayed on average a faster weight increase than females. In the case of Japanese eel the backcalculated total lengths of males at each of the ages before downstream spawning migration was not significantly different from those of females in the corresponding ages (Fig. 3). This indicated that the existence of a difference in growth rates of eels between males and females is still controversial.

The sex differentiation of the eels is labile and influenced by environmental factors (Colombo \& Rossi, 1978) and the testis-like gonad of the yellow eels is primitive and possibly reversible (Colombo et al., 1984). In other words, the sex of eels is determined environmentally (Krueger \& Oliveira, 1999). The $\mathrm{Sr}$ : Ca ratios in otoliths indicated that the migratory environmental history of the eels during the growing phase was similar between males and females. Accordingly, it is possible that the total length of males at each age before downstream spawning migration was consistent with that of females at the corresponding ages. On the other hand, the mean total length of females over 6 years old was significantly larger than that of males. This is because females postpone the age at migration to achieve larger size while males approach an asymptotic length. The phenomenon that males enter the migrating silver eel stage at lower mean age and size than females was found also in the European eel (Helfman et al., 1987; Vøllestad, 1992) and other fishes, possibly because larger females can produce more eggs to maximize their reproductive success (Wenner \& Musick, 1974; Wootton, 1984).

This study was financially supported by the National Science Foundation, Republic of China (Contract No. NSC 88-2311-B-002-043). We thank T. F. Tsai and two anonymous reviewers for helpful comments on an early draft of the manuscript.

\section{References}

Bellini, A. (1970). Expériences sur l'élévage de l'anguille en stabulation à Comacchio. Bulletin de la Société Centrale d'Aquiculture et de Pêche, Paris III-x, 1-40.

Cheng, P. W. \& Tzeng, W. N. (1996). Timing of metamorphosis and estuarine arrival across the dispersal range of the Japanese eel Anguilla japonica. Marine Ecology Progress Series 131, 87-96.

Colombo, G. \& Rossi, R. (1978). Environmental influences on growth and sex ratio in different eel populations (Anguilla anguilla L.) of Adriatic coasts. In Physiology and Behavior of Marine Organisms (McLusky, D. S. \& Berry, A. J., eds), pp. 320-331. Oxford: Pergamon Press. 
Colombo, G., Grandi, G. \& Rossi, R. (1984). Gonad differentiation and body growth in Anguilla anguilla L. Journal of Fish Biology 24, 215-228.

Francis, R. I. C. C. (1990). Back-calculation of fish length: a critical review. Journal of Fish Biology 36, 883-902.

Guan, R., Wang, X. \& Ke, G. (1994). Age and growth of eels Anguilla japonica in a Chinese river. Journal of Fish Biology 45, 653-660.

Helfman, G. S., Facey, D. J., Hales, L. S. Jr \& Bozenam, E. L. Jr (1987). Reproductive ecology of the American eel. American Fisheries Society Symposium 1, 42-56.

Holmgren, K. \& Mosegaard, H. (1996). Implications of individual growth status on the future sex of the European eel. Journal of Fish Biology 49, 910-925.

Kalish, J. M. (1990). Use of otolith microchemistry to distinguish the progeny of sympatric anadromous and non-anadromous salmonidae. U.S. Fishery Bulletin 88, 657-666.

Krueger, W. H. \& Oliveira, K. (1999). Evidence for environmental sex determination in the American eel, Anguilla rostrata. Environmental Biology of Fishes 55, 381-389.

Kuhlman, H. (1975). The influence of temperature, food, size, and origin on the sexual differentiation of elvers (Anguilla anguilla). Helgoländer Wissenschaftliche Meeresuntersuchungen 27, 139-155 (in German with English abstract).

Poole, W. R. \& Reynolds, J. D. (1996). Growth rate and age at migration of Anguilla anguilla. Journal of Fish Biology 48, 633-642.

Ricker, W. E. (1958). Handbook of computations for biological statistics of fish populations. Bulletin of Fishery Research Board of Canada 119, 1-300.

Rossi, R. \& Colombo, G. (1976). Sex ratio, age and growth of silver eels in two brackish lagoons in the northern Adriatic Valli of Comacchio and Valle Nuova. Archives of Oceanography \& Limnology 18, 325-341.

Tesch, F. W. (1977). The Eel: Biology and Management of Anguillid Eels. Translated from Germany by J. Greenwood. New York: Chapman \& Hall.

Tsukamoto, K. (1992). Discovery of the spawning area for Japanese eel. Nature 356, $789-791$.

Tsukamoto, K., Nakai, I. \& Tesch, F. W. (1998). Do all freshwater eels migrate? Nature 396, 635.

Tzeng, W. N. (1985). Immigration timing and activity rhythms of the eel, Anguilla japonica, elvers in the estuary of northern Taiwan, with emphasis on environmental influences. Bulletin of the Japanese Society of Fishery Oceanography 47/48, $11-28$.

Tzeng, W. N. (1990). Relationship between growth rate and age at recruitment of Anguilla japonica elvers in a Taiwan estuary as inferred from otolith growth increments. Marine Biology 107, 75-81.

Tzeng, W. N. (1995). Migratory history recorded in otoliths of the Japanese eel, Anguilla japonica, elvers as revealed from SEM and WDS analyses. Zoological Studies 34(Suppl. 1), 234-236.

Tzeng, W. N. (1996). Effects of salinity and ontogenetic movements on strontium : calcium ratios in the otoliths of the Japanese eel, Anguilla japonica Temminck and Schlegel. Journal of Experimental Marine Biology and Ecology 199, $111-122$.

Tzeng, W. N. \& Tsai, Y. C. (1992). Otolith microstructure and daily age of Anguilla japonica Temminck \& Schlegel elvers from the estuaries of Taiwan with reference to unit stock and larval migration. Journal of Fish Biology 40, 845-857.

Tzeng, W. N. \& Tsai, Y. C. (1994). Changes in otolith microstructure of the Japanese eel, Anguilla japonica, during its migration from the ocean to the rivers of Taiwan. Journal of Fish Biology 45, 671-684.

Tzeng, W. N., Wu, H. F. \& Wickström, H. (1994). Scanning electron microscopic analysis of annulus microstructure in otolith of European eel, Anguilla anguilla. Journal of Fish Biology 45, 479-492.

Tzeng, W. N., Severn, K. P. \& Wickström, H. (1997). Use of otolith microchemistry to investigate the environmental history of European eel Anguilla anguilla. Marine Ecology Progress Series 149, 73-81. 
Tzeng, W. N., Severn, K. P., Wickström, H. \& Wang, C. H. (1999). Strontium bands in relation to age marks in otoliths of European eel Anguilla anguilla. Zoological Studies 38(4), 452-457.

Tzeng, W. N., Wang, C. H., Wickström, H. \& Reizenstein, M. (2000). Occurrence of the semi-catadromous European eel Anguilla anguilla (L.) in the Baltic Sea. Marine Biology 137, 93-98.

Vladykov, V. D. (1966). Remarks on the American eel (Anguilla rostrata Le Sueur): size of elvers entering streams; the relative abundance of adult males and females; and present economic importance of eels in North American. Verhandlungen der Internationale Vereingung für Theoretische and Angewandte Limnologie 16, 1007-1017.

Vøllestad, L. A. (1992). Geographic variation in age and length at metamorphosis of maturing European eel: environmental effects and phenotypic plasticity. Journal of Animal Ecology 61, 41-48.

Vøllestad, L. A. \& Jonsson, B. (1986). Life-history characteristics of the European eel Anguilla anguilla in the Imsa River, Norway. Transactions of the American Fisheries Society 57, 983-997.

Wenner, C. A. \& Musick, J. A. (1974). Fecundity and gonad observations of the American eel, Anguilla rostrata, migrating from Chesapeake Bay, Virginia. Journal of Fisheries Research Board of Canada 31, 1387-1391.

Wootton, R. J. (1984). Introduction: strategies and tactics in fish reproduction. In Fish Reproduction: Strategies and Tactics (Potts, G. W. \& Wootton, R. J., eds), pp. 1-12. New York: Academic Press. 